OPEN ACCESS

Edited by:

Anabela Carvalho,

University of Minho, Portugal

Reviewed by:

Bruno Takahashi,

Michigan State University,

United States

Hollie Smith,

University of Rhode Island,

United States

${ }^{*}$ Correspondence:

Catherine V. Schmitt

catherine.schmitt@maine.edu

Specialty section:

This article was submitted to Science and Environmental Communication,

a section of the journal

Frontiers in Communication

Received: 09 October 2017

Accepted: 14 March 2018

Published: 03 April 2018

Citation:

Schmitt CV (2018) Push or Pull:

Recommendations and Alternative

Approaches for Public Science

Communicators.

Front. Commun. 3:13.

doi: 10.3389/fcomm.2018.00013

\section{Push or Pull: Recommendations and Alternative Approaches for Public Science Communicators}

\author{
Catherine V. Schmitt* \\ Maine Sea Grant College Program, University of Maine, Orono, ME, United States
}

The news media is a primary source of science information for American adults. News stories are often driven by press releases and other communications "pushed" by institutions, publishers, organizations, and private companies. This article, from the perspective of a public science communicator, examines and critiques push communications, offers some best practices for press releases, and presents examples of other "pull" approaches to communicating science that more closely align with both the process of science and with the interests and values of public audiences.

Keywords: science news, science journalism, press releases, writing, public audiences

\section{INTRODUCTION}

The majority of American adults receive no formal instruction in science beyond high school (National Center for Education Statistics, 2016). While some seek out science news and sciencethemed media, most are exposed to science in a passive manner, reading science stories as they come across them in general news sources (Funk et al., 2017).

News media thus are a target for science communications professionals. While the desire for media coverage is nothing new, several trends are affecting news that have implications for science communication. These include fewer science reporters employed by the news media, an "attention economy" that demands more frequent and attractive news, and a diversified media landscape created by the Internet. Scientists themselves are increasingly oriented toward the media as academic performance evaluation encourages being in the spotlight (Dunwoody, 2014; Weingart and Guenther, 2016; Weingart, 2017).

Combined, these trends have resulted in a greater flow of science press releases (Autzen, 2014). Charged with promoting science and/or the work of scientific institutions, journal publishers, press officers, and staff science writers "push" their message out to the media. Marcinkowski and Kohring (2014) distinguish this from "pull" communication, where "the communicator makes his/her information available to an anonymous and dispersed public through appropriate channels, which can then be selected and 'pulled' on by recipients according to their individual interests."

As a science communicator employed by a publicly funded science organization at a public university, I find that this push/pull distinction provides a helpful framework for examining science communication in the context of "news."

I do not challenge the assumption that public organizations are obligated to inform and involve citizens (Lohwater and Storksdieck, 2017) or secure legitimacy for science funding (Weingart and Guenther, 2016). But is news the right media for fulfilling these obligations? 
In my work, I am not preoccupied with institutional branding or attention garnering. Does that make me an anomaly, as Bauer et al. (2013) would suggest? In fact, each of the 33 Sea Grant programs employs at least one communicator whose job is to communicate about funded research, but also science in general, with an emphasis on providing quality and useful information. Sea Grant programs removed media metrics from annual performance measures over a decade ago.

Still, institutional and political pressures to "get coverage" persist. For example, exchanges on the National Association of Science Writers member listserv for public information officers (PIOs) regularly discuss writing press releases and the merits and pitfalls of various media attention strategies that suggest outside influence-PIOs are responding to some explicit or implicit directive, from within or beyond their office, to write and place news stories. Yet, PIOs also question whether news is the right format for communicating science.

Here, I explore this question and present evidence, based primarily on my experience, supporting both best practices for "pushing" stories and alternative, "pulling" approaches to science communication.

\section{THE PUSH IS ON}

Push communication has become the dominant form of public science communication (Marcinkowski and Kohring, 2014). The majority of science news occurs after research projects are completed and results are published in a peer-reviewed journal (Funk et al., 2017). Science news is driven by journal publishers and the researchers' host institutions, who distribute embargoed press releases and story packages for journal articles they deem important.

Students and beginning reporters are often taught to "start with the press release" (e.g., Appiah and Cassasbuenas, 2016). Press releases explain the study's significance to reporters who are assumed to be crushing against deadline (Jackson and Moloney, 2016; Oransky and Marcus, 2016). This system has led to a process in which just a handful of sources (e.g., Science, Nature) set the news agenda (Hermida, 2010). In a kind of "reactive journalism" (Jackson and Moloney, 2016), reporters tend to cover the same stories so as not to miss out, resulting in the same stories reported by different outlets at the same time.

Increasingly, press releases are quoted from without attribution, or reprinted in full as reported stories ("churnalism"; Harcup, 2004; Davies, 2008; Lewis et al., 2008; Jackson and Moloney, 2016; Shipman, 2016; Johnston and Forde, 2017).

The desire to get in the news creates an emphasis on hype that, while enticing, gives too little attention to the relevance of science for the average person or the quality of the research (Bubela et al., 2009; Rehman, 2013; Bilton, 2016; Weingart, 2017). After news discoveries, the most common science stories are about "strange or weird" research findings (Funk et al., 2017). Press releases and news stories exaggerate claims of significance, even though readers think news outlets are too quick to report findings that may not 'hold up"' (Funk et al., 2017).

Such claims are pervasive in the fields of health and nutrition (Woloshin and Schwartz, 2002; Bohannon, 2015), even though exaggeration does not increase the likelihood of news coverage (Sumner et al., 2016).

Supporting the idea that a scientific paper or research finding represents a conclusion or aha! discovery of some kind has been called one of the biggest failures of science reporting (Robbins, 2010). Marcinkowski and Kohring (2014) go so far as to call push communication a threat to the autonomy of scientific research.

The problem here is not necessarily with news or press releases or hype or attention-seeking. The problem is when these practices are combined with science, because they often violate the knowledge-generating norms of science itself: accounting for contradictory evidence, specifying the level of confidence attached to findings, and precise expression of hypothesis, methods, and findings. The "production infrastructure" of the news media is asynchronous with science: episodic instead of chronic, short instead of long, urgent instead of cautious. Science communication should adhere to these norms; otherwise the science itself is called into question. This relationship differentiates science communication from other forms of public information sharing (Jamieson, 2017) and is more supportive of pull communications (discussed further below).

However, science is newsworthy. The media (print and online newspapers and magazines, television, radio) consider information "news" based on its timeliness, novelty, conflict, and agency. So, when does it make sense to push a communication?

\section{WHEN SCIENCE IS NEWS: RECOMMENDATIONS FOR PUSH COMMUNICATION}

Despite the above criticisms, publication in a journal qualifies as an "event" with obvious timeliness. As Autzen (2014) noted, the press release-media story pattern is "already a well-run ecosystem" unlikely to change anytime soon. It would be hard for any science communicator to abandon journal article press releases entirely.

When writing a story based on a journal article, the writer must strive to avoid heightening claims of significance, and to place the article in context with previous research and what research comes next. Other best practices include citing funding sources, providing links to the journal article and research labs, as well as suggesting ways readers might take action on a given issue (Purcell et al., 2010; Russell, 2010); and provide evidence, rather than the words of an expert telling people what to think (Brown, 2009).

Many funding agencies and grant recipients issue announcements at the time of a new award for scientific research. Money is news, and public audiences deserve to know about new research, especially if the funding is from a public agency. The grantor wants the world to know that money is being spent and how. The grantee wants to demonstrate their success in competing for funds, and generate excitement about (and attention to) the research to come. A benefit of these announcements is that the funding source is a main point of the story, whereas this credit tends to get lost when science is reported at later stages (Cook et al., 2007).

However, in the attempt to attract attention, even new project announcements can overstate the potential impact of the research. 
Such overstatement might derive from the original proposal to the funder, or might come from the researcher after prompting by the writer (who is under pressure to get coverage).

Writing about a new grant does not translate into continued coverage. With a constant focus on "new" research and results, news writers rarely follow-up to see what became of previously reported research and whether or not the suggested impacts were ever realized (e.g., Dumas-Mallet et al., 2017). The news of the grant remains untethered to the news of the results. This could lead to mistrust among readers, if they feel they are always reading about new projects, but never find out what happened. Lack of follow-up also miscommunicates the process of science, and thus fails to improve public understanding of science no matter how well-written the story. Issuing an announcement of new work comes with a commitment to following the work as it proceeds, and providing an accessible location for readers to access information about project status and outcomes.

A given research project is rarely a new idea. New studies build on previous work. What might be new is the investigator, the group of investigators or collaborators, the location of research, the hypothesis, or the method. Focusing on the period between a funding award and journal publication is more synchronous with the process of science. Most Americans do not understand the concept of a scientific study and news media may be contributing to this misunderstanding (Miller, 2010).

Science can be news during the research process: when researchers conduct field experiments, when they present their work, or when research poses opportunities for stakeholder engagement. Communicating about science as it happens provides an opportunity to humanize science, such as through interviews and profiles (Bubela et al., 2009). These in medias res stories are often more difficult to write, as they require time and ability to visit field sites. They can be more difficult to publish if editors do not consider them newsworthy, although they can become part of a longer investigative or synthetic story published later. Unlike prepackaged journal articles, in-process science pieces result in better stories that are not being written by every other reporter (Russell, 2010).

One successful "news" angle for these stories is research conducted by scientists at local institutions or research happening in the local environment, as nearly three-quarters of American adults follow local news closely (Miller et al., 2012). Stories about science in the neighborhood or region show that science is everywhere, and does not only happen at large research institutions or distant exotic locations.

Science is news when the question being investigated or results have urgency or significance to a specific audience. As Weingart and Guenther (2016) said, "if the science is relevant, useful, interesting, one does not need to work very hard to attract attention." However, from the perspective of a publicly funded science organization, push communication requires a knowledge of what motivates people's concern for and interest in an issue (Bubela et al., 2009), what questions they have, and what format(s) for communication is most appropriate to the audience(s).

Research on salient issues cannot be communicated in a single press release, especially research that addresses societal concerns, as is the case with most publicly funded projects. Relevant, applied science demands that public science communicators balance pushing with pulling.

\section{BEYOND THE NEWS: ALTERNATIVE APPROACHES FOR PULL COMMUNICATION}

As cited in the Introduction, most people passively consume "science" news through general news sources (Funk et al., 2017). This exposure is severely limited, as science makes up about $2 \%$ or less of the news media (National Science Board, 2016). It is risky for a public science communicator to rely on chance or casual encounter with science content as part of the crowded and rapid news cycle.

In the "stampede of coverage" that follows journal article press releases, opportunities for distinctive reporting are few (Robbins, 2010; Rennie, 2011). Some reporters will not cover "old" research results, even studies that appeared online a week or two earlier. News writers can rarely look back to see what (if anything) became of the "discoveries" they previously reported (Rennie, 2011). Rather than trying to attract the stampede, science communication professionals can do the work that news writers cannot.

Data about information-seeking habits support pull communication approaches. When people have specific science-related questions or interests, they search the Internet (Brossard and Scheufele, 2013; National Science Board, 2016). A goal of pull communication is to supply content that will satisfy search results. This is especially important to counter the volume of misinformation and "pseudoscience" available online. Since it is less reliant on timeliness, pull communication can be revised and updated in order to remain pertinent over longer periods of time than news media.

The key to successful pull communications is identifying what information people need or desire, now or in the future. Even when not practicing push communication, it is still important to follow the news and gain a sense for the issues. In my work, this accounts for most of my interaction with media: informally assessing public information needs. Science communicators can then respond by providing context, explanation, and analysis (see Masnick and Zimmerman, 2009); for example, by tracking research on a given topic over time (Hermida, 2010; Rehman, 2013), addressing "frequently asked questions" (e.g., Kaczor, 2015), or filling gaps in media coverage that have been identified (e.g., Schmitt, 2014; Wilcox, 2016). Given the decline in journalism staffs and funding, public science communicators are well suited to fill expanding roles of civic educators and curators, aggregating and making sense of existing news and controversies (Fahy and Nisbet, 2011). Science communicators can work with laboratories and departments to create content driven by stakeholder needs. Continued responsiveness over time can help an institution or organization build a reputation as a trusted source of science-based information.

Another way to assess information needs is through direct engagement with audiences, for example through informal events, open houses, "ask a scientist" features, and partnerships with 
local land trusts, museums, and other science-related centers. Most Americans (62\%) have encountered science information in the past year at an informal learning venue, such as a park, zoo, or museum; 16\% participated in a citizen science project (Funk et al., 2017). Participatory models make the scientific process more interactive and encourage discussion of scientific issues (Secko et al., 2013). These activities serve to raise awareness of research while also providing an informal assessment of target audience interests and information needs, which can then be addressed with additional science content.

Is there a danger in providing information directly to the public without any "quality check by gatekeepers such as journalists" (Weingart and Guenther, 2016)? The gatekeeping function is inherent to the practice of science. As long as science communicators adhere to the norms and values of science, pull communication can be less fraught with potential for error, hype, and confusion.

\section{CONCLUSION}

The pressure for public science communicators to attract attention and "get coverage" is real, although further study of such pressures is needed. Why are science messages "pushed" through a blurry realm of science, the media, marketing, and public relations (Weingart, 2017)? Who is really doing the pushing?

Push communication may not always be the best approach for public science communicators charged with enhancing scientific

\section{REFERENCES}

Appiah, B., andCassasbuenas, J. (2016). HowtoReportScientific Findings. SciDev.Net. Available at: http://www.scidev.net/global/communication/practical-guide/ how-to-report-scientific-findings.html (Accessed: October 9, 2017).

Autzen, C. (2014). Press releases-the new trend in science communication. J. Sci. Commun. 13, C02.

Bauer, M. W., Howard, S., Ramos, R., Jessica, Y., Massarani, L., and Amorim, L. (2013). Global Science Journalism Report: Working Conditions \& Practices, Professional Ethos and Future Expectations. London: Science and Development Network.

Bilton, R. (2016). Connecting Science with Society, Undark Hopes to Elevate the Standards for Science Journalism. NiemanLab. Available at: http://www.niemanlab.org/2016/10/connecting-science-with-society-undark-hopes-to-helpelevate-the-standards-for-science-journalism/ (Accessed: October 9, 2017).

Bohannon, J. (2015). I Fooled Millions into Thinking Chocolate Helps Weight Loss. Here's How. Gizmodo.com. Available at: https://io9.gizmodo.com/i-fooledmillions-into-thinking-chocolate-helps-weight- 1707251800

Brossard, D., and Scheufele, D. A. (2013). Social science, science, new media, and the public. Science 339, 40-41. doi:10.1126/science.1232329

Brown, D. (2009). Science Reporting and Evidence-Based Journalism. The American Scholar. Available at: https://theamericanscholar.org/science-reporting-andevidence-based-journalism/.

Bubela, T., Nisbet, M. C., Borchelt, R., Brunger, F., Critchley, C., Einsiedel, E., et al. (2009). Science communication reconsidered. Nat. Biotechnol. 27, 514-518. doi:10.1038/nbt0609-514

Cook, D. M., Boyd, E. A., Grossmann, C., and Bero, L. A. (2007). Reporting science and conflicts of interest in the lay press. PLoS ONE 2:e1266. doi:10.1371/ journal.pone. 0001266

Davies, N. (2008). Flat Earth News. London, UK: Chatto \& Windus.

Dumas-Mallet, E., Smith, A., Boraud, T., and Gonon, F. (2017). Poor replication validity of biomedical association studies reported by newspapers. PLOS ONE 12:e0172650. doi:10.1371/journal.pone.0172650 literacy, legitimizing public support for science, and providing information for making societal and political decisions.

"Pull" methods of communicating science more closely align with the process of science, the goals of publicly funded and nonprofit institutions, and with the interests and values of public audiences. Implementing these approaches might influence public understanding of science, while also generating interesting and well-written science stories across multiple media outlets.

The challenge is finding the willingness and capacity to take a different approach. Connecting practitioners with research on science news beyond health and medical sciences, evaluations of push versus pull communications, and understanding more about the media and information needs and preferences of target audiences would support science communicators and writers who want to push less and pull more.

\section{AUTHOR CONTRIBUTIONS}

The author confirms being the sole contributor of this work and approved it for publication.

\section{FUNDING}

This work was supported by the University of Maine and U.S. Department of Commerce, National Oceanic and Atmospheric Administration grant number NA14OAR4170072.

Dunwoody, S. (2014). "Science journalism," in Routledge Handbook of Public Communication of Science and Technology, eds M. Bucchi and B. Trench (Abingdon: Routledge). Available at: https://www.routledgehandbooks.com/

Fahy, D., and Nisbet, M. C. (2011). The science journalist online: shifting roles and emerging practices. Journalism 12, 778-793. doi:10.1177/1464884911412697

Funk, C., Gottfried, J., and Mitchell, A. (2017). Science News and Information Today. Pew Research Center. Available at: http://www.journalism.org/2017/09/20/ science-news-and-information-today/ (Accessed: September 17, 2017).

Harcup, T. (2004). Journalism Principles and Practice. London: SAGE.

Hermida, A. (2010). "Revitalizing science journalism for a digital age," in Science and the Media, eds D. Kennedy and G. Overholser (Cambridge, MA: American Academy for Arts and Sciences), 80-87. Available at: https://www.amacad.org/ content/publications/publication.aspx? $\mathrm{d}=334$

Jackson, D., and Moloney, K. (2016). Inside churnalism. Journalism Stud. 17, 763-780. doi:10.1080/1461670X.2015.1017597

Jamieson, K. H. (2017). "The need for a science of science communication: communicating science's values and norms," in The Oxford Handbook of the Science of Science Communication, eds K. H. Jamieson, D. Kahan, and D. Scheufele (New York, NY: Oxford University Press), 15.

Johnston, J., and Forde, S. (2017). Churnalism. Digit. Journalism 5, 943-946. doi:10.1080/21670811.2017.1355026

Kaczor, K. (2015). Seaweed Accumulation on Maine's Coastal Beaches. Maine Sea Grant College Program. Available at: http://www.seagrant.umaine.edu/blog/ seaweed-on-beaches (Accessed: January 11, 2018).

Lewis, J., Williams, A., and Franklin, B. (2008). Four rumours and an explanation: a political economic account of journalists' changing newsgathering and reporting practices. Journalism Pract. 2, 27-45. doi:10.1080/17512780701768493

Lohwater, T., and Storksdieck, M. (2017). "Science communication at scientific institutions," in The Oxford Handbook of the Science of Science Communication, eds K. H. Jamieson, D. Kahan, and D. Scheufele (New York, NY: Oxford University Press), 179.

Marcinkowski, F., and Kohring, M. (2014). The changing rationale of science communication: a challenge to scientific autonomy. J. Sci. Commun. 13, C04. 
Masnick, A. M., and Zimmerman, C. (2009). Evaluating scientific research in the context of prior belief: hindsight bias or confirmation bias? J. Psychol. Sci. Technol. 2, 29-36. doi:10.1891/1939-7054.2.1.29

Miller, C., Purcell, K., and Rosenstiel, T. (2012). 72\% of Americans Follow Local News Closely. Pew Research Center and the Knight Foundation. Available at: http://www.pewinternet.org/2012/04/12/72-of-americans-follow-local-newsclosely/ (Accessed: October 9, 2017).

Miller, J. D. (2010). "Civic scientific literacy: the role of the media in the electronic era," in Science and the Media, eds D. Kennedy and G. Overholser (Cambridge, MA: American Academy for Arts and Sciences), 44-63. Available at: https:// www.amacad.org/content/publications/publication.aspx?d=334 (Accessed: October 9, 2017).

National Center for Education Statistics. (2016). Digest of Education Statistics, 2015 (NCES 2016-014). U.S. Department of Education. Available at: http://nces. ed.gov/programs/digest/ (Accessed: October 9, 2017).

National Science Board. (2016). Science and Engineering Indicators 2016. Available at: https://www.nsf.gov/statistics/2016/nsb20161/\#/

Oransky, I., and Marcus, A. (2016). Press Releases Stink. Here's Why That Matters. Stat. Available at: https://www.statnews.com/2016/02/10/press-releases-stink/ (Accessed: October 9, 2017).

Purcell, K., Rainie, L., Mitchell, A., Rosenstiel, T., and Olmstead, K. (2010). Understanding the Participatory News Consumer. Pew Research Center. Available at: http://www.pewinternet.org/2010/03/01/understanding-the-participatorynews-consumer/ (Accessed: October 9, 2017).

Rehman, J. (2013). The Need for Critical Science Journals. UK Guardian. Available at: https://www.theguardian.com/science/blog/2013/may/16/need-for-criticalscience-journalism (Accessed: October 9, 2017).

Rennie, J. (2011). Time for Change in Science Journalism? UK Guardian. Available at: https:/www.theguardian.com/science/2011/jan/26/science-online-2011journalism-blogs (Accessed: October 9, 2017).

Robbins, M. (2010). Why I Spoofed Science Journalism, and How to Fix It. UK Guardian. Available at: http://www.guardian.co.uk/science/the-lay-scientist/2010/sep/28/science-journalism-spoof?intcmp=239 (Accessed: October 9, 2017).

Russell, C. (2010). "Covering controversial science: improving reporting on science and public policy," in Science and the Media, eds D. Kennedy and G. Overholser (Cambridge, MA: American Academy for Arts and Sciences), 111-118. Available at: https://www.amacad.org/content/publications/publication.aspx?d=334
Schmitt, C. (2014). On Jellyfish. Maine Sea Grant College Program. Available at: http://www.seagrant.umaine.edu/blog/jellyfish (Accessed: January 11, 2018).

Secko, D. M., Amend, E., and Friday, T. (2013). Four models of science journalism: a synthesis and practical assessment. Journalism Pract. 7, 62-80. doi:10.1080/1 7512786.2012 .691351

Shipman, M. (2016). News Releases Exaggerate the Results of Scientific ResearchA New Study Shows Why This Should Stop. Health News Review. Available at: http://www.healthnewsreview.org/2016/12/news-releases-exaggerate-theresults-of-scientific-research-a-new-study-shows-why-this-should-stop/ (Accessed: October 3, 2017).

Sumner, P., Vivian-Griffiths, S., Boivin, J., Williams, A., Bott, L., Adams, R., et al. (2016). Exaggerations and caveats in press releases and health-related science news. PLOS ONE 11:e0168217. doi:10.1371/journal.pone. 0168217

Weingart, P. (2017). "Is there a hype problem in science? If so, how is it addressed?" in The Oxford Handbook of the Science of Science Communication, eds K. H. Jamieson, D. Kahan, and D. Scheufele (New York, NY: Oxford University Press), 111-118.

Weingart, P., and Guenther, L. (2016). Science communication and the issue of trust. J. Sci. Commun. 15, C01.

Wilcox, C. (2016). Don't Fear the Jellygeddon. Hakai Magazine. Available at: https:// www.hakaimagazine.com/news/dont-fear-jellygeddon/ (Accessed: August 11, 2016).

Woloshin, S., and Schwartz, L. M. (2002). Press releases: translating research into news. J. Am. Med. Assoc. 287, 2856-2858. doi:10.1001/jama.287.21.2856

Conflict of Interest Statement: The author declares that the research was conducted in the absence of any commercial or financial relationships that could be construed as a potential conflict of interest.

Copyright (C) 2018 Schmitt. This is an open-access article distributed under the terms of the Creative Commons Attribution License (CC BY). The use, distribution or reproduction in other forums is permitted, provided the original author(s) and the copyright owner are credited and that the original publication in this journal is cited, in accordance with accepted academic practice. No use, distribution or reproduction is permitted which does not comply with these terms. 